\title{
The development of the Indonesian college student social anxiety scale
}

Suryaningrum, Cahyaning $\bowtie$

Universitas Gadjah Mada, Indonesia (cahyaning.suryaningrum@mail.ugm.ac.id)

Retnowati, Sofia

Universitas Gadjah Mada, Indonesia (sofi_53@ugm.ac.id)

Helmi, Avin Fadilla

Universitas Gadjah Mada, Indonesia (avinpsi@ugm.ac.id)

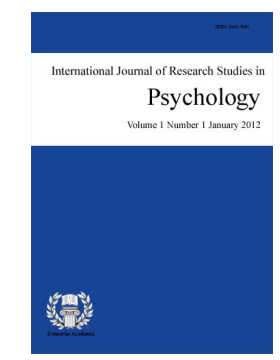

ISSN: 2243-7681 Online ISSN: 2243-769X

OPEN ACCESS

Hasanat, Nida Ul

Universitas Gadjah Mada, Indonesia (nida@ugm.ac.id)

\section{Abstract}

Social anxiety among Indonesian college students is still high. Therefore a screening tool is needed for prevention to be done optimally. Indonesia has a very wide cultural diversity, so it needs to construct social anxiety instrument in accordance with the culture of Indonesian society. The respondents were 664 students from several universities in Malang, East Java, Indonesia. A measuring instrument is considered good if it has high validity and reliability. The results showed that Social Anxiety Scale has content validity with Aiken V value from $0.838-0.975$. The construct validity was tested by model fit test with parameter value GFI = 0,916; $\mathrm{AGFI}=0.880 ; \mathrm{CFI}=0.938 ; \mathrm{RMSEA}=0.064$. Reliability of the instruments is 0.931 . Property-based testing shows that the Social Anxiety Scale has been empirically tested.

Keywords: social anxiety; Indonesian college students; development scale; reliability; validity 


\section{The development of the Indonesian college student social anxiety scale}

\section{Introduction}

Most Indonesian college students still have social anxiety. A total of $43.12 \%$ of 211 students at a college in Malang experiencing social anxiety (Suryaningrum, 2006). Similar results in 2014; $42.5 \%$ of 120 students also experienced social anxiety. Similarly, in 2015, 52.2\% of the 364 students from three universities in Malang, East Java, experience low-moderate social anxiety; while 24.7\% included high social anxiety (Suryaningrum, 2016). This research uses a Liebowitz Social Anxiety Scale-Self Report (LSAS-SR) that has been translated into Indonesian for data collection.

In line with Suryaningrum's findings, Hasibuan, Srisayekti, and Moeliono (2015) who used the Liebowitz Social Anxiety Scale (LSAS) showed that $20.9 \%$ of 255 students of a college in Bandung experienced social anxiety at the low level, $47.8 \%$ at the moderate level, and $31.2 \%$ at the high level. The results of Vriends, Pfaltz, Novianti, and Hadiyono (2013) showed that Indonesian university students are more anxious than Swiss university students.

Social anxiety refers to the tendency to be nervous in social situations. Social situations include performance situations (e.g., speaking or performing in front of others and social interaction situations (e.g., meeting unfamiliar people or authority figures). Anxious people will be afraid of getting negative evaluation from others who make themselves feel embarrassed (American Psychiatric Association [APA], 2013; McNeil, Randall, Lejuez, \& Sorrell, 2014), looking stupid (APA, 2013; Antony \& Swinson, 2008; Henderson, Gilbert, \& Zimbardo, 2014), and cause rejection or discomfort (APA, 2013; Henderson et al., 2014). Social anxiety can result in social relationships, job success, and education (Antony \& Swinson, 2008; Butler, 1999), adaptation at universities (Nordstrom, Goguen, \& Hiester, 2014), academic performance (Levpusceek \& Berce, 2012), and quality in conveying opinions (Mesa, Beidel, \& Bunnel, 2014).

One of the problems faced when conducting social anxiety research in Indonesia is instrument to measure social anxiety comes from abroad which is certainly less fit with Indonesian culture. Besides research from Hasibuan et al. (2015) and Suryaningrum (2016), an example of social anxiety research in Indonesia that uses abroad instrument namely: the research of Avianty, Yusainy, and Fitriani (2016) that uses the Social Interaction Anxiety Scale (SIAS) from Mattick and Clarke; Pramitasari and Ariana (2014) who used Social Anxiety Scale-Adolescent (SAS-A) from La Greca and Lopez; Rachmawaty's study (2015) using the Liebowitz Social Anxiety Scale for Children and Adolescents (LSAS-CA) from Liebowitz; and research on Swasti and Martani (2013) who used the Interaction Anxiousness Scale (IAS) of Leary.

SIAS and IAS focus more on the anxiety of social interaction situations (Brown et al., 1997; Leary \& Kowalski, 1993); while the frequent source of anxiety in college student's life is in the performance situation. LSAS-CA focuses on social anxiety in children (Fresco et al., 2001); while SAS-A focuses on high school adolescents (Nelemans, et al., 2017). So that scale is not appropriate when used to measure social anxiety on college students.

Liebowitz's Social Anxiety Scale-Self Report (LSAS-SR) is a popular social anxiety scale used by researchers to identify the level of social anxiety. The scale was compiled in 1987 by Michael Liebowitz; a Psychiatrist and researcher from Columbia College and the New York State Psychiatric Institute. Preparation of this instrument is actually more intended for use in clinical diagnosis. Research has shown that this scale has a high internal consistency $(\alpha=0.90-0.96)$ and retest reliability of 0.82 (dos Santos, Loureiro, Crippa, \& Osorio, 2013).

There is another social anxiety scale, the scale of Social Anxiety Questionnaire for Adults (SAQ-A30) 
The development of the Indonesian college student social anxiety scale

compiled by Caballo, Salazar, Irurtia, Arias, and CISO-A Research Team in 2010, which is the result of research from 18 Latin American countries (Caballo, Salazar, Irurtia, Arias, \& CISO-A Research Team, 2012). Items of the LSAS-SR and SAQ-A30 are less suited to the social situations commonly encountered in the life of Indonesian college students. Here's an example, "Looking at people you don't know very well in the eyes"; "Resisting a high pressure salesperson". In SAQ-A30 there are also examples of items such as, "Having to ask a neighbor to stop making noise"; "Asking someone I find attractive to dance"; "Looking into the eyes of someone I have just met while we are talking". These items are an example that is less suitable to the context of life and role as a college student also encourages Indonesian respondents to tend not to answer "low" on the level of anxiety. This is because of Indonesian society, a so-called collectivist society, a dominant society with interdependence values and norms of courtesy (polite), respect, tolerance and harmony (Koentjaraningrat, 2009; Soekanto, 2000; Dokhi et al., 2016).

Based on the above explanation it can be concluded that the instrument used to measure social anxiety in Indonesian society, including for college student samples, need to be adjusted to align with Indonesian culture. Research on social anxiety among Indonesian college students is important with considering the quite high level of social anxiety (Hasibuan et al. 2015; Suryaningrum, 2016; Vriends et al., 2013). Meanwhile, the role of college students in political life is very strong and important, for example as agents of change, social agents, also as moral and control agents against the government. Therefore, the construction of the Indonesian-based instrument has become relevant and urgent.

The Social Anxiety Scale designed by the researcher is expected to reflect the real social situations felt or experienced by Indonesian college students and have taken into consideration the cultural context of Indonesian society. The concept or theory used in the preparation of this instrument is based on the Diagnostic and Statistical Manual of Mental Disorders ( $5^{\text {th }}$ ed.; DSM-5; APA, 2013) both regarding definitions and social situations that give rise to social anxiety. Although the theoretical foundation used is relatively the same as other abroad social anxiety instruments, the difference from this research is that all the indicators outlined in the item are excavated from the field (bottom-up). By doing this way it is expected that indicators of social anxiety will be fit to the social situations most Indonesian college students worry as collectivist societies. Findings related to this will be able to enrich the development of social anxiety theory in a cultural context. Social situations that are worried by a society (e.g., collectivistic-individualistic; interdependent-independent) may not always be the same or have their own peculiarities.

Based on the above explanation, the purpose of this research is to construct and provide psychometric information about the Social Anxiety Scale on Indonesian college students. The benefits of this research are the availability of a more valid and reliable measuring tool to measure the level of social anxiety in harmony with Indonesian college students. Through a valid and reliable instrument, and in line with the cultural background, more accurate data will be generated to reflect the conditions measured. Thus interventions designed to overcome cases of social anxiety among Indonesian college students are expected to be more appropriate. In addition, the results of this study, namely the availability of an instrument of social anxiety based on Indonesian culture, will be beneficial for practitioners, educators, and academics who are interested in exploring research related to social anxiety among Indonesian college students.

\section{Methods}

\subsection{Respondents}

This research is quantitative with a focus on developing measuring instruments. The sampling technique is purposive sampling or judgmental sampling. Inclusion criteria or respondent requirement is Indonesian college students who have never settled in an outside country in suppose getting a sample that truly represents a collectivist society. The respondents involved in this study were 664 college students who had completed the 
third semester, both men and women; comes from several universities in Malang. Students who have passed through the third semester are considered to have been able to adapt to the university world. It is hoped that the responses given to the research instrument items are responses to social anxiety; not anxiety due to adaptation issues. The data retrieval procedure is done directly within a class with permission from the lecturer and upon approval of the respondents. Respondents who are willing to engage in research are given informed consent. There are two stages in building a scale. Respondents in the first stage were 129 college students who were involved in the bottom-up; while 25 college students are involved in the language feasibility test. In the second stage, there were 510 college students involved in item discrimination analysis and construct validity test.

\subsection{Data analysis}

Pearson product-moment correlation was used to analyze discrimination in items. The Aiken's formula V was performed to achieve content validity. Construct validity done through exploratory and confirmatory factor analysis. Confirmatory factor analysis was conducted through the measurement model test using Structural Equation Model (SEM). The reliability approach of the scale uses an internal consistency coefficient (Alpha formula). IBM SPSS 22 was used to compute product-moment correlation, exploratory factor analysis and internal consistency coefficient (Alpha). AMOS version 22 is used to perform confirmatory factor analysis.

\subsection{Research procedure}

\section{Stage 1: Preparation of indicators and items}

The aspects of social anxiety used in the scale are derived from the DSM-5 (APA, 2013). These aspects include (1) Anxious in performance situations, and (2) Anxious in social interaction situations. Indicators arranged based on each aspect are extracted from the field (bottom-up) using an open-ended questionnaire. Questions include: in what situations they often feel anxious and they are asked to give examples of the anxiety they feel when in that situation as much as possible. Based on the excavation of indicators from 129 respondents, the following results are obtained: (1) In performance situations, they feel anxious when: a) perform in front of many people, and b) express an opinion. (2) In situations of social interaction, they report feeling anxious when: a) interacting with authority figures, and b) interacting with new people.The response to these respondents is the most answer they report. The indicators that are the result of the exploration are then used as the basis for compiling items of the Social Anxiety Scale.

Test language is done first before doing empirical test items that exist in scale. The language feasibility test is performed to ascertain whether the sentence used in the preparation of the item is understandable to the reader and to the will of the researcher (Azwar, 2016). The language feasibility test is conducted by 25 undergraduate students. They are asked to look at every sentence /item and respond by ticking $(\sqrt{ })$ in the understand column and do not understand columns. Discussion between student and researcher is done to repair item when student respond does not understand on a sentence /item. Based on the aspects, indicators and feasibility test of the language that has been done then produced a blueprint of Social Anxiety Scale on college students which can be seen in Table 1.

\section{Table 1}

Blueprint of Social Anxiety Scale

\begin{tabular}{|c|c|c|c|c|}
\hline Aspect & Indicator & Weight & Total Item Scale & Total Item Test \\
\hline $\begin{array}{l}\text { Anxiety in a performance } \\
\text { situation }\end{array}$ & $\begin{array}{l}\text { Perform in front of many } \\
\text { people } \\
\text { Express opinion }\end{array}$ & $60 \%$ & 9 & 30 \\
\hline $\begin{array}{l}\text { Anxiety in a social } \\
\text { interaction situation }\end{array}$ & $\begin{array}{l}\text { Interacting with authority } \\
\text { figures } \\
\text { Interacting with new people }\end{array}$ & $40 \%$ & 6 & 20 \\
\hline & Total & $100 \%$ & 15 & 50 \\
\hline
\end{tabular}


The development of the Indonesian college student social anxiety scale

Field findings show that students are more concerned about performance situations. That's why more items are required that represent the performance aspect. The scaling of social anxiety responses is a continuum. Students are asked to select a number in the range of 1-7 on each item to show how anxious about the social situation. Value 1 indicates very low anxiety level, value 7 indicates an extremely high level of anxiety; the middle value (4) indicates moderate anxiety level. All responses given by student respondents totaled a total score. The higher the total score indicates the higher the level of social anxiety of a student.

\section{Stage 2: the empirical test}

Empirical test aims to test the quality of items on respondents who have characteristics equivalent to the respondents who will be subject to scale (Azwar, 2016). The data obtained from the test respondents will be used as the basis for analyzing the discrimination of items, exploratory and confirmatory factor analysis (construct validity). Previously it is necessary to test the validity of the content, i.e., the test on the extent to which scale items logically measure the relevant and representative aspects with which to be measured (Azwar, 2016).

\section{Results}

\subsection{Content validity}

Content validity test was conducted by 20 appraisers (rater) i.e., students of the Doctoral Program of Psychology Universitas Gadjah Mada (UGM). The results of the rater were calculated using the Aiken or Aiken's $\mathrm{V}$ formula. The number of assessors was 20 rater and 5 response categories, using $p=.01$, the minimum value of index V was .69 (Aiken, 1985). Based on the calculation results, obtained results of index V values moving between .838 - .975; more than the minimum value of index V is .69. With these results, the Anxiety Scale that been arranged has good content validity.

\subsection{Item discrimination analysis}

510 students became respondents for the item discrimination analysis. Correlation coefficient value specified in this study that is at least .30 (Azwar, 2016). Based on the results of discrimination analysis of items, from 50 items analyzed all showed correlation coefficient above .30 ranged from .462 - .776. Furthermore, the selection of items based on the highest order of power discrimination coefficient value by considering the representation of indicators in building aspects or construct. The number of selected items is as many as 15 items, in accordance with the predefined blue-print. Next factor analysis is done on the 15 items selected to see if the item has represented aspects of the construct being measured.

\subsection{Factor analysis}

255 college students became respondents for factor analysis. The criteria used to define a viable item to maintain are items that have a minimum load factor of 0.40 (Hair, Black, Babin, \& Anderson, 2010). Table 2 is the result of the factor analysis of 15 items selected. Table 2 shows all items well distributed according to the factor or aspect. The value of the factor load on the aspect of the performance situation ranges from .475- .757. The value of factor loads on aspects of the social interaction situation ranges from .600 to .787. Based on these results it can be said that the selected items have decent factor load and have represented the aspect.

\subsection{Confirmatory factor analysis}

Then the items that have been produced based on the exploratory factor analysis are tested to determine whether the indicators that have been compiled are valid indicators as a latent constituent measure through confirmatory factor analysis. Construct validity seen from significance and value of indicator factor to latent construct (Hair et al., 2010). 255 college students were included for confirmatory factor analysis. Confirmatory 
Suryaningrum, C., Retnowati, S., Helmi, A. F., \& Hasanat, N. U.

factor analysis was conducted through the measurement model test using Structural Equation Model (Arbuckle, 2013; Hair et al., 2010; Maruyama, 1998). A model is said to be compatible with empirical conditions when the GFI value is $\geq .90 ; \mathrm{AGFI} \geq .80 ; \mathrm{CFI} \geq .90 ;$ and $\mathrm{RMSEA}$ value $\leq .08$ (Arbuckle, 2013). Based on model test, the result of GFI $=.916 ;$ AGFI $=.880 ;$ CFI $=.938$; and RMSEA $=.064$. This indicates that the model has compatibility with empirical conditions. Thus it can be concluded that the aspects and indicators that make up the scale have supported the constituents. The model test results can be seen in Figure 1.

Table 2

The Result of factor analysis

\begin{tabular}{ccc}
\hline $\begin{array}{c}\text { Item number } \\
\text { selected }\end{array}$ & $\begin{array}{c}\text { Factor 1 } \\
\text { (Aspects of performance situation) }\end{array}$ & $\begin{array}{c}\text { Factor 2 } \\
\text { (Aspects of social interaction situation) }\end{array}$ \\
\hline 2 & .475 & \\
9 & .739 & \\
13 & .665 & .639 \\
20 & .744 & .411 \\
21 & & \\
27 & .610 & .600 \\
28 & .733 & \\
31 & & \\
32 & .757 & .754 \\
35 & .736 & .780 \\
40 & & .787 \\
41 & & .775 \\
46 & & \\
48 & .629 & \\
50 & &
\end{tabular}

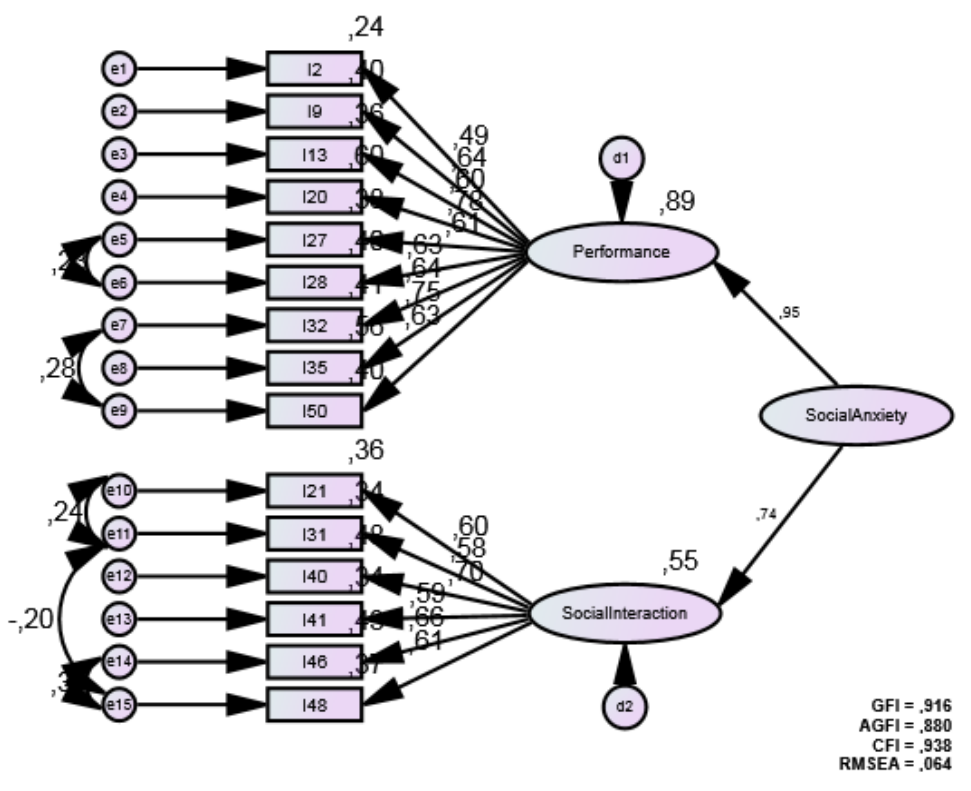

Figure 1.Confirmatory factor analysis of Social Anxiety Scale Model

The summary of the estimation results of the contribution of aspects to the latent construct and the contribution of the indicator (item) to aspects can be seen in Table 3. Based on Table 3, the performance loading factor value was $.946(p<.01)$ in support of social anxiety construct while the coefficient value of social interaction aspect is .741 $(p<.01)$ in support of social anxiety construct. Items on the performance aspect have loading factor from $.491-.775$ (all significant with a value of $p<.01$ ); while the items on the social interaction aspect have a loading factor from .579 to .696 (all of which are also significant with $p<0.01$ ). These results 
The development of the Indonesian college student social anxiety scale

indicate that the indicators that make up the performance aspect, as well as social interaction can explain the theoretical construct.

\section{Table 3}

Standardized regression weights on the Social Anxiety Scale

\begin{tabular}{llll}
\hline & Paths & & Estimate \\
\hline Performance & $<---$ & Social Anxiety & $.946^{* *}$ \\
Social Interaction & $<---$ & Social Anxiety & $.741^{* *}$ \\
I2 & $<---$ & Performance & $.491^{* *}$ \\
I9 & $<---$ & Performance & $.636^{* *}$ \\
I13 & $<---$ & Performance & $.597^{* *}$ \\
I20 & $<---$ & Performance & $.775^{* *}$ \\
I27 & $<---$ & Performance & $.612^{* *}$ \\
I28 & $<---$ & Performance & $.630^{* *}$ \\
I32 & $<---$ & Performance & $.639^{* *}$ \\
I35 & $<---$ & Performance & $.751^{* *}$ \\
I50 & $<---$ & Performance & $.634^{* *}$ \\
I48 & $<---$ & Social interaction & $.610^{* *}$ \\
I46 & $<---$ & Social interaction & $.655^{* *}$ \\
I41 & $<---$ & Social interaction & $.587^{* *}$ \\
I40 & $<---$ & Social interaction & $.696^{* *}$ \\
I31 & $<---$ & Social interaction & $.579^{* *}$ \\
I21 & $<---$ & Social interaction & $.598^{* *}$ \\
\hline I & & &
\end{tabular}

\subsection{Reliability}

According to Azwar (2016) a good reliability value for a measuring instrument that is $>.80$, whereas according to Gable and Wolf (1993) the reliability of the measuring instrument for the affective component of .70 is still acceptable. The calculation results show that the scaled scale has a reliability value of .931 . Reliability on the performance aspect is .911 ; while reliability on the social interaction aspect is .862 . Based on these results it can be concluded that the Social Anxiety Scale compiled is a reliable scale. The results of reliability calculations on each of the following items resulting in the total-item correlation from each item can be seen in Table 4.

\section{Table 4}

Reliability aspect and item-total correlation

\begin{tabular}{|c|c|c|c|c|}
\hline Aspect & Reliability & Item Number & Corrected item-total correlation & Alpha if item deleted \\
\hline \multirow[t]{9}{*}{ Performance } & 0.911 & 2 & .545 & .911 \\
\hline & & 9 & .675 & .902 \\
\hline & & 13 & .698 & .901 \\
\hline & & 20 & .728 & .898 \\
\hline & & 27 & .692 & .901 \\
\hline & & 28 & .727 & .898 \\
\hline & & 32 & .725 & .899 \\
\hline & & 35 & .732 & .898 \\
\hline & & 50 & .710 & .900 \\
\hline \multirow[t]{6}{*}{ Social Interaction } & 0.862 & 21 & .603 & .848 \\
\hline & & 31 & .660 & .838 \\
\hline & & 40 & .686 & .833 \\
\hline & & 41 & .671 & .836 \\
\hline & & 46 & .708 & .830 \\
\hline & & 48 & .602 & .848 \\
\hline
\end{tabular}


Based on Table 4, all items have a correlated item-total correction which is quite high (above .30) in both performance aspect and social interaction aspect. This means that items are items that have a good power difference and will decrease the reliability value when the item is removed (see Table 4 in the column "Cronbach's Alpha if the item is deleted "). Thus it can be concluded based on the results of calculation of reliability and validity that has been done that Social Anxiety Scale on the college students being compiled is a valid and reliable scale.

The last step is to assemble the selected items and test them into the order of the items in accordance with the measured aspect. Table 5 is a Social Anxiety Scale ready to use.

\section{Table 5}

Social Anxiety Scale on College students who have been tested

\begin{tabular}{llcc}
\hline \multicolumn{1}{c}{ Aspect } & \multicolumn{1}{c}{ Indicator } & $\begin{array}{c}\text { Item number in the } \\
\text { study }\end{array}$ & $\begin{array}{c}\text { Item number in the } \\
\text { resulting scale }\end{array}$ \\
\hline $\begin{array}{l}\text { Anxiety in a performance } \\
\text { situations }\end{array}$ & perform in front of many people & $9,13,20,28,32$, & $2,3,4,7,9,10,15$ \\
& express an opinion & 35,50 & 1,6 \\
Anxiety in a social interaction & $\begin{array}{l}\text { Interacting with authority } \\
\text { situation }\end{array}$ & $21,31,40$ & $5,8,11$ \\
& $\begin{array}{l}\text { figures } \\
\text { interacting with new people }\end{array}$ & $41,46,48$ & $12,13,14$ \\
\hline
\end{tabular}

\section{Discussion}

The process of preparing Social Anxiety Scale in the research has been done according to the procedure required in the preparation of a measuring instrument, namely the determination of construct, the arrangement of scale items, empirical test on a number of respondents, and psychometric property test that is the validity and reliability scale (Azwar, 2016; Furr, 2011). The results show that the college student Social Anxiety Scale that has been compiled is valid and reliable. $\mathrm{V}$ value index of .838 to .75 indicates that this scale has good content validity. Based on the construct validity test, from the exploratory factor analysis it is found that the items have been well distributed according to their aspect with the loading factor value of $.475-.757$ on the performance aspect; and .600 - .787 on aspects of social interaction situation. The loading factor value has met the requirements of a proper retention rule that is at least 0.40 as provided by Hair et al. (2010).

In addition, based on the confirmatory factor analysis, it was found that the measurement model of Social Anxiety Scale has been fit with GFI value $=.916$; AGFI $=.880 ; \mathrm{CFI}=.938$; and RMSEA $=.064$. The value of the loading factor aspect that explains the social anxiety construct is all significant $(p<.01)$, that is equal to .946 on the performance aspect and .741 on the social interaction aspect. Similarly, on the item of loading factor on all aspects is also significant $(p<.01)$ in explaining the theoretical construct. The value of the loading factor aspect of performance ranges from .491 - .775; whereas items on aspects of social interaction have a factor loading from .579 to .696 . The reliability of this scale shows that this scale is reliable with a reliability value of .931. Reliability of the performance aspect is .911; while reliability for social interaction is .862 . Based on the data that have been mentioned can be concluded that Social Anxiety Scale on college students is a valid and reliable measure to measure social anxiety level of Indonesian college students.

The peculiarities of this scale are items that are arranged based on indicators obtained from the field. Several studies of social anxiety in Indonesia such as Dharmawan and Dariyo (2017), Lestari (2012), and Mutahari (2016) studies have used self-prepared social anxiety tools but indicators/items were not obtained through "bottom up". As indicators come from the field, the items arranged on this scale are items that measure social anxiety in social situations that are actually experienced by Indonesian college students in general in their roles and lives as college students. This scale has concerned the contextual aspects of social anxiety experienced by Indonesian college students; in specific situations felt by Indonesian college students. Indirectly, this scale has 
The development of the Indonesian college student social anxiety scale

also paid attention to the cultural aspects of social anxiety experienced by Indonesian college students as members of a collectivist community.

The most response given by the college students based on the indicators obtained in the field shows that the performance situation is a more worrisome aspect compared with the social interaction situation. Based on these findings, and then in the preparation of this scale the number of items aspects of the performance situation more than the aspect of social interaction situation. Based on confirmatory factor analysis, performance aspect contributed more to social anxiety construct with coefficient value .946 compared to social interaction aspect with .741, when viewed from weight or aspect load. This is consistent with data from the field that social anxiety that students feel more in the performance situations than the social interaction situation.

More specifically, in the most worrisome performance situations by college students is when performing in front of many people and when expressing an opinion. The situation is interpreted by the students as a situation that is likely to give greater negative evaluation from others. This interpretation is inseparable from the characteristics of Indonesian college students as collectivist society which put forward interdependence values such as maintaining social harmony, aligning with thoughts-feelings-actions of others (Markus \& Kitayama, 1991, 2010) refrain from self-effacing (Kagitcibasi, 2005). The number of items on the indicator performs in front of many people ie: seven (7) items with load factor values based on the confirmatory factor analysis of .597 - .775. The number of items on the indicator to get an opinion is two (2) items with a factor load value of.491 -.612 .

In the aspect of social interaction, an anxious indicator is generated when interacting with authority figures and anxious when interacting with new people. There is no more dominant indicator worried about students. Nevertheless, there are interesting things found in the selection of an item on the anxious indicator that is interacting with the authority figure. In situations of interaction with authority figures, items related to anxiety associated with the lecturer have a high item-total correlation (items 21,31, and 40). While items related to other authority figures (the head of the institution, senior, and an expert) have a low item-total correlation index. It can be concluded that there are peculiarities related to college students' social anxiety in the context of interaction with authority figures that must be considered in the preparation of scale; namely choosing the interaction items with the lecturer because it has a high item discrimination index. When factor analysis is performed, these three items are well distributed on the factor with a factor load value $>0.60$.

Based on the above description can be said that the preparation of the Social Anxiety Scale is based on real conditions. This means that according to the reported by college students related to social situations that they are worried about. It distinguishes this scale from the scale of social anxiety from the outside (e.g., LSAS-SR, SAQ-30A, SIAS, SAS-A, and IAS) that have been used in Indonesia as well as the scale of social anxiety compiled by other researchers from Indonesia. The scale compiled in this study is a specific scale for measuring social anxiety among Indonesian college students. SIAS and IAS focus more on anxiety on social interaction situations than performance situations. LSAS-CA and SAS-A focus on social anxiety of children and adolescents. LSAS-SR and SAQ-30A are scale used to measure the level of social anxiety in general. All of these abroad scales, the social situations raised are, of course, also a situation prevalent in their culture.

\section{Conclusion}

The conclusion of this research is the result of measuring instrument of Social Anxiety Scale on the college student that is in contact with the real social situation worried by the college students. Means that the resulting scale has paid attention to the cultural context because it is specifically related to social anxiety experienced by Indonesian college students as members of collectivist society. Social Anxiety Scale is worthy of use as a measuring tool to identify social anxiety levels in college students. This is based on the results of the scale validity test (including content validity and construct validity) which states that this scale is valid. The reliability test results also state that this scale is reliable and the items arranged have an internal- consistency correlation 
index in accordance with the requirements.

Suggestions for further researchers are to sharpen the search of indicators from the field by enriching the indicator through other methods such as Focused Group Discussion, or individual interviews other than open questionnaires as has been done in this study. In addition, it would be interesting if conducted a qualitative research to find aspects or dimensions of social anxiety typical of Indonesian college students. There is an interesting thing that can be developed from this study is to examine this Social Anxiety Scale in a sample of college students from other countries who are collectivist countries. Will the same psychometric information be produced? Thus studies of culture-based social anxiety scales will be more developed.

Acknowledgments - The research reported in this manuscript is part of doctoral dissertation of first author, funded by the Directorate of Higher Education, Ministry of Education and Culture based on the Letter of Scholarship number 1420 / E4.4 / 2014. Appreciation goes to funder and research respondents.

\section{References}

Aiken, L. R. (1985). Three coefficients for analyzing the reliability and validity of ratings. Educational and Psychological Measurement, 4, 131-142. https://doi.org/10.1177/0013164485451012

American Psychiatric Association (2013). Diagnostic and statistical manual of mental disorders (5th ed.). Washington, DC: American Psychiatric Association. https://doi.org/10.1176/appi.books.9780890425596

Antony, M .M., \& Swinson, R. P. (2008). Shyness \& social anxiety workbook (2nd ed.). Canada: New Harbinger Publications, Inc.

Avianty, S. K., Yusainy, C. A., \& Fitriani, A. (2016). Pengaruh self-control training terhadap kecemasan sosial pada remaja [Self control training effects on adolescent's social anxiety]. Academia. Retrieved from http://www.academia.edu

Arbuckle, J. L. (2013). Amos 22.0 user"s guide. Chicago: IBM SPSS.

Azwar, S. (2016). Penyusunan skala psikologi [Psychological scale construction] (2nd ed.). Yogyakarta: Pustaka Pelajar.

Brown, E. J., Turovsky, J., Heimberg, R. G., Juster, H. R., Brown, T. A., \& Barlow, D. H. (1993). Validation of the social Interaction anxiety scale and the social phobia scale across the anxiety disorders. Psychological Assessment, 9(1), 21-27. https://doi.org/10.1037/1040-3590.9.1.21

Butler, E. G. (1999). Overcoming social anxiety and shyness. London: Constable \& Robinson Ltd.

Cabalo, V. E., Salazar, I. C., Irurtia, M. J., Arias, B., \& Hofmann, S. G., \& CISO-A Research Team. (2012). The multidimensional nature and multiculture validity of a new measure of social anxiety: The Social Anxiety Questionnaire for Adults. Behavior Therapy, 43, 313-328. https://doi.org/10.1016/j.beth.2011.07.001

Dharmawan, U. S., \& Dariyo, A. (2017). Hubungan moral integrity dan kecemasan sosial dengan academic dishonesty remaja akhir [The relationship of moral integrity and social anxiety with the academic dishonesty in late adolescent].Provitae Jurnal Psikologi Pendidikan, 10(2), 80-97.

Dokhi, M., Siagian, T. H., Sukim, Wulansari, I. Y., Hadi, D. W., \& Sambodo, N. (2016). Analisis kearifan lokal ditinjau dari keragaman budaya [Analysis of local wisdom in terms of cultural diversity].Pusat Data dan Statistik Pendidikan dan Kebudayaan. Kementrian Pendidikan dan Kebudayaan Republik Indonesia.

dos Santos, L. F., Loureiro, S. R., Crippa, J. A. d. S., \& Osorio, F. d. L. (2013). Psychometric validation study of Liebowitz Social Anxiety-Scale-Self-Reported version of Brazilian Portuguese. PLoS ONE, 8(7). https://doi.org/10.1371/journal.pone.0070235

Fresco, D. M., Coles, M. E., Heimberg, R. G., Liebowitz, M. R., Hami, S., Stein, M. B., \& Goetz, D. (2001). The Liebowitz Social Anxiety Scale: A comparison of psychometric properties of self-report and clinician-administered formats. Psychological Medicine, 31, 1025-1035. 
The development of the Indonesian college student social anxiety scale

https://doi.org/10.1017/S0033291701004056

Furr, R. M. (2011). Scale construction and psychometrics for social and personality psychology. London: Sage. https://doi.org/10.4135/9781446287866

Gable, R. K., \& Wolf, M. B. (1993). Instrument development in the affective domain: Measuring attitudes and values in corporate and school setting. (2nd ed.). New York: Springer Science + Business Media. https://doi.org/10.1007/978-94-011-1400-4

Hair Jr, J. F., Black, W. C., Babin, B. J., \& Anderson, R. E. (2010). Multivariate data analysis (7th ed.). London: Pearson Prentice Hall.

Hasibuan, E. P. N., Srisayekti, W., \& Moeliono, M. F. (2015). Gambaran kecemasan sosial berdasarkan Liebowitz Social Anxiety Scale (LSAS) pada remaja akhir di Bandung [An overview of social anxiety based on the Liebowitz Social Anxiety Scale (LSAS) in late adolescent in Bandung]. Jurnal Publikasi Berkala Penelitian Pascasarjana Universitas Padjajaran, 1-10.

Henderson, L., Gilbert, P., \& Zimbardo, P. (2014). Shyness, social anxiety, and social anxiety disorder. In S.G. Hofman \& P.M. DiBartolo (Eds.), Social anxiety. Clinical, development, and social perspectives (3rd ed., pp. 95 - 115). London: Elsevier.

Kagitcibasi, G. (2005). Autonomy and relatedness in cultural context. Implications for self and family. Journal of Cross-cultural Psychology, 36 (4), 403-422. https://doi.org/10.1177/0022022105275959

Koentjaraningrat. (2009).Pengantar ilmu antropologi [Introduction to anthropology sciences]. Jakarta: Rineka Cipta.

Leary, M. R., \& Kowalski, R. M. (1993). The interaction anxiousness scale: Construct and criterion-related validity. Journal of Personality Assesment, 61(1), 136-146. https://doi.org/10.1207/s15327752jpa6101_10

Lestari, E.S. (2012). Hubungan kecemasan social dan kematangan emosi dengan kematangan seksual remaja SMP di kabupaten Bantul Yogyakarta [The relationship of social anxiety and emotional maturity with the junior high school's sexual maturity in Bantul, Yogyakarta]. Psikopedagogia, 1(1), 1-12. https://doi.org/10.12928/psikopedagogia.v1i1.2568

Levpuscek, M.P. \& Berce, J. (2012). Social anxiety, social acceptance and academic self-perceptions in high-school students. Drus. Istraz. Zagreb God, 2(116), 405-419. https://doi.org/10.5559/di.21.2.06

Markus, H. R., \& Kitayama, S. (1991). Culture and the self: Implications for cognition, emotion, and motivation. Psychological Review, 98(2), 224-253. https://doi.org/10.1037/0033-295X.98.2.224

Markus, H. R., \& Kitayama, S. (2010). Culture and selves: A cycle of mutual constitution. Perspectives on Psychological Science, 5(4), 420-430. https://doi.org/10.1177/1745691610375557

Maruyama, G. M. (1998). Basics of structural equation modeling. California: Sage. https://doi.org/10.4135/9781483345109

McNeil, D. W., Randall, C. L., Lejuez, C. W., \& Sorrell, J. T. (2014). Mechanisms of learning and behavior change in social anxiety disorder. In S. G. Hofman \& P. M. DiBartolo, (Eds.), Social anxiety. Clinical, development, and social perspectives (3rd ed., pp. 451-481). London: Elsevier. https://doi.org/10.1016/B978-0-12-394427-6.00015-7

Mesa, F., Beidel, D. C., \& Bunnel, B. E. (2014). An examination of psychopathology and daily impairment in adolescents with social anxiety disorder. PloS One 9(4). https://doi.org/10.1371/journal.pone.0093668

Mutahari, H. (2016). Hubungan antara kepercayaan diri dengan kecemasan social pada siswa kelas VII SMP Negeri 2 Kalasan tahun ajaran 2015-2016 [The relationship between self-confidence with social anxiety in the seventh grade students of SMP Negeri 2 Kalasan in 2015-2016 academic year]. E-Journal Bimbingan dan Konseling, 3(5), 13-23.

Nelemans, S. A., Meeus, W. H. J., Branje, S. J. T., Leeuwen, K. V., Colpin, H., Verschueren, K., \& Goossens, L. (2017). Social anxiety for adolescent (SAS-A) short form: Longitudinal measurement invariance in two community samples of youth. Assessment, 1-14. https://doi.org/10.1177/1073/191116685808

Nordstrom, A. H., Goguen, L. M. S., \&Hiester, M. (2014). The effect of social anxiety and self-esteem on college adjustment, academics, and retention. Journal of College Counseling, 17, 48-63. https://doi.org/10.1002/j.2161-1882.2014.00047.x 
Suryaningrum, C., Retnowati, S., Helmi, A. F., \& Hasanat, N. U.

Pramitasari, S. \& Ariana, A. D. (2014). Hubungan antara konsep diri fisik dan kecenderungan kecemasan sosial pada remaja awal [The relationship between physical self-concept and social anxiety tendencies in early adolescent]. Jurnal Psikologi Klinis dan Kesehatan Mental, 3(1), 48- 3.

Rachmawaty, F. (2015). Peran pola asuh orang tua terhadap kecemasan social pada remaja [Parenting roles to social anxiety in adolescents]. Jurnal Psikologi Tabularasa, 10(1), 31-42.

Soekanto, S. (2000). Sosiologi. Suatu pengantar [Sociology. An introduction]. Jakarta: Rajawali Pers.

Suryaningrum, C. (2006). Indikasi gangguan kecemasan pada mahasiswa FakultasPsikologi Universitas Muhammadiyah Malang [Anxiety disorder indication in college students Psychology Faculty of Universitas Muhammadiyah Malang].Unpublished manuscript, Lembaga Penelitian Universitas Muhammadiyah Malang.

Suryaningrum, C. (2016). Kecemasan social mahasiswa: Studi pendahuluan [Social anxiety on college students: Preliminary study]. Paper presented at the National Seminar on Recent Research in Behavioral Science on November 26, 2016, Universitas Gadjah Mada, Yogyakarta

Swasti, I. K., \&Martani, W. (2013). Menurunkan kecemasan social melalui pemaknaan kisah hidup [Reducing social anxiety through the meaning of life story]. Jurnal Psikologi, 40(1), 39-58.

Vriends, N., Pfaltz, M. C., Novianti, P., \& Hadiyono, J. (2013). Taijin kyofusho and social anxiety and their clinical relevance in Indonesia and Switzerland. Frontiers in Psychology, 4(3), 1-9.

https://doi.org/10.3389/fpsyg.2013.00003 


\section{Appendix}

\section{Social Anxiety Scale on College Student}

Instruction:

1. Below are some of the usual situations encountered by students that may cause discomfort. Nevertheless, the inconvenience is VERY REASONABLE because many students are experiencing it. If you have not faced yet, IMAGINE HOW IF YOU ARE IN SUCH SITUATIONS

2. Respond according to your own circumstances, related: The feeling of anxiety you feel because FEAR GETS NEGATIVE ASSESSMENT BY OTHERS in those situations

3. Write the answer in the Anxiety Level column by ticking $(\sqrt{ })$

4. All the answers you provide are true, no answer is considered wrong

Guide to Answer:

Anxiety level

$\begin{array}{ll} & \\ \text { Very low } & \text { Moderate }\end{array}$

\begin{tabular}{|c|c|c|c|c|c|c|c|c|}
\hline No. & Situation & \multicolumn{7}{|c|}{ Anxiety Level } \\
\hline & & $\begin{array}{c}1 \\
\text { Very } \\
\text { Low } \\
\end{array}$ & 2 & 3 & 4 & 5 & 6 & $\begin{array}{c}7 \\
\text { Very } \\
\text { High }\end{array}$ \\
\hline 1. & Expressing disagreement in meetings / discussions & & & & & & & \\
\hline 2. & Giving a talk in front of an audience & & & & & & & \\
\hline 3. & Performing on stage that made me the center of attention & & & & & & & \\
\hline 4. & Giving a speech in front of many people & & & & & & & \\
\hline 5. & Talking to a lecturers about thesis report / theme & & & & & & & \\
\hline 6. & Expressing opinions during meetings / discussions & & & & & & & \\
\hline 7. & Opening an event that many people attend & & & & & & & \\
\hline 8. & Meeting with a lecturer to consult an assignment / thesis & & & & & & & \\
\hline 9. & Speaking in scientific forums attended by many people & & & & & & & \\
\hline 10. & Leading a meeting in front of many people & & & & & & & \\
\hline 11. & Have to contact the lecturer to request an appointment & & & & & & & \\
\hline 12. & Starting a conversation with an older person & & & & & & & \\
\hline 13. & Attending an event that made me have to interact with new people & & & & & & & \\
\hline 14. & Meeting people I don't know & & & & & & & \\
\hline 15. & Expressing ideas in scientific forums attended by many people & & & & & & & \\
\hline
\end{tabular}


Suryaningrum, C., Retnowati, S., Helmi, A. F., \& Hasanat, N. U. 